\title{
CONTRAJUNÇÃO E VELHICE: TRADIÇÃO E OBSOLESCÊNCIA
}

João Carlos Cattelan*

Resumo: Este estudo se dedica à observação do discurso ordinário (um tipo discursivo que se pauta na trivialidade, na efemeridade e na reiteração da ordem discursiva). O foco de análise incide sobre enunciados construidos com conectivos contrajuntivos, em especial com o mas adversativo. Busca-se resgatar o saber anterior, produzido antes, em outro lugar e independentemente, que atravessa perpendicularmente o discurso produqiido no eixo dêitico do aqui e agora, e ter acesso a sustentáculos que comandam as articulações entre as partes do enunciado. Observa-se, então, como enunciados contrajuntivos opõem proposições entre si, quando a temática em pauta se refere à longevidade dos homens e das coisas.

Palavras-chave: Discurso ordinário. Polifonia. Contrajunção. Velhice.

\section{INTRODUÇÃO}

A clivagem do sujeito por uma alteridade é assumida no conceito de polifonia, seja ela concebida aos moldes de Ducrot (1987) ou de Bakhtin (1997). Em ambos, ela remete à constitutividade do eu e do outro no enunciado. A relação interlocutiva demanda, pois, que vozes antecedam o discurso para que o discurso se torne possível. Quando se defende que a consciência resulta de fatores sociológicos, a originalidade é um mito.

Um enunciado que parece pertencer à soberania unificadora do sujeito não possui um centro de perspectiva, sendo, portanto, polifônico, ainda que aparente homofonia e silencie a heterogeneidade que o constitui. Nele, estão vozes que aparecem, de forma crucial, quando, no intradiscurso, elas são marcadas como distintas: seja por meio da

\footnotetext{
* Docente da Universidade Estadual do Oeste do Paraná, em Marechal Cândido Rondon e em Cascavel. O autor possui doutorado pela Unesp, campus de Araraquara. E-mail: cattelan@brturbo.com.br.
} 
polifonia que se mostra no enunciado ou daquela que remete a vozes exteriores, o homem é voz entre vozes. ${ }^{1}$

Perceba-se a formação polifônica desse intróito: ele se pauta em Bakhtin, para quem a dialogia é crucial, pois a consciência humana se faria por meio de compreensões responsivas, e a Ducrot, para quem o enunciado é atravessado por pontos de vista distintos. As concepções de polifonia de Bakhtin e de Ducrot são distintas. Considera-se, aqui, a teoria polifônica de Ducrot. Para ele, a polifonia remete ao fato de, num enunciado, haver vozes não atribuíveis a um sujeito apenas, o que permite "criticar e substituir a teoria da unicidade do sujeito da enunciação", que dá como evidente "que há um ser único autor do enunciado e responsável pelo que é dito no enunciado" (p. 178).

Objetiva-se, com o estudo de enunciados contrajuntivos ligados à velhice, observar as vozes que habitam essa produção e a perspectiva que estabelecem em relação a essa etapa da vida. Assume-se que, por detrás das partes $\mathbf{A}$ e $\mathbf{B}$ de um enunciado contrajuntivo, existe um enunciado $\mathbf{C}$ que legitima o raciocínio inferencial e provém de uma voz social anterior que impõe uma formulação. Num enunciado contrajuntivo, ouvem-se vozes distintas, sendo elas, pelo menos, a do locutor e a do diz-se: enunciador genérico eleito como visada razoável.

Um enunciado construído com um operador argumentativo contrajuntivo faz soarem vozes simultâneas e realiza os seus objetivos, seja por meio da promessa de atendimento de desejos, seja pelo alerta para os perigos que se corre. Assume-se que o uso da polifonia é uma forma de sujeição aos ditames sociais; afinal de contas, por que os homens falariam se não fosse para alcançar o que desejam?

\footnotetext{
${ }^{1} \mathrm{O}$ fulcro teórico deste estudo tem como background de reflexão a teoria polifônica de Ducrot (1987), embora, pontualmente, aqui ou ali (e às vezes de forma muito enfática), possa recorrer a noções que provêm da Análise de Discurso: entende-se não se constituir num paradoxo irreconciliável recorrer a estes conceitos, dado que, em sentido lato, os pleitos da Pragmática Linguística não são intrinsecamente contraditórios com aquela disciplina.
} 


\section{A POLIFONIA DUCROTIANA}

Para Ducrot $(1987)^{2}$, os estudos linguísticos teriam assumido que, num enunciado, há um só ponto de vista. Para o autor, a concepção reinou intocada até ser posta em dúvida por Bakhtin, na Literatura, mas, neste caso, a teoria teria "sempre [sido] aplicada a textos, ou seja, a sequências de enunciados, jamais aos enunciados de que estes textos são constituídos" (p. 161). Ducrot assume que a unicidade subjetiva não se sustenta, constitui uma teoria polifônica da enunciação e defende que, no enunciado, existem várias vozes.

$\mathrm{O}$ autor conceitua significação como as "instruções que especificam que manobras realizar para associar um sentido a um enunciado" (p. 170) e sentido como a "qualificação da enunciação" pelo enunciado (p. 172). Ele afirma que, para a compreensão do sentido, deve-se considerar o fato de ser produzido por vozes que têm origens distintas e que se mesclam na pretensa voz unitária de um sujeito global e centralizador.

Dentre as vozes, Ducrot separa a que pertenceria ao locutor, que seria "um ser que, no próprio sentido do enunciado, apresenta-se como seu responsável, ou seja, como alguém a quem se deve imputar a responsabilidade do enunciado" (p. 182); ele seria o responsável pela proferição do enunciado, a ficção discursiva que produz um ato de fala, o que permite postular a existência de três: um, a quem se deve o dizer (o locutor propriamente dito ou a personagem discursiva); outro, que coincide com o ser do mundo (que pode ser responsabilizado pelo ato ilocutório); e outro, ainda, que deixa marcas de primeira pessoa no enunciado (eis os casos de discurso relatado). Essa tripartição enunciativa possibilitaria múltiplas formas de polifonia.

Seja o exemplo: Meu médico me disse: você está doente. Para Ducrot, existiriam, neste enunciado, três locutores: aquele que, interno ao enunciado, é o responsável pela sua emissão; aquele que, exterior ao enunciado, foi ao médico, recebeu o aviso e se marca como primeira pessoa com me e meu; e o médico, que diz, em primeira pessoa: você está

\footnotetext{
2 Como já se escreveram outros textos e, neles, utilizou-se como amparo a teria polifônica da enunciação de Ducrot (1987), esta seção fatalmente acabará ficando parecida com outras já escritas: parece que não há outro caminho de a discussão acontecer: no limite, obter-se-ão paráfrases do jádito.
} 
doente. O exemplo, como se percebe, revela uma forma tríplice de polifonia de locutores.

Haveria também os enunciadores. Eles não deixariam marcas de primeira pessoa, mas seriam responsáveis pelos pontos de vista. Ducrot os define como "seres que são considerados como se expressando através da enunciação, sem que para tanto se lhes atribuam palavras precisas; se 'falam' é somente no sentido em que a enunciação é vista como expressando seu ponto de vista, sua posição, sua atitude, mas não, no sentido material do termo, suas palavras" (p. 192). Neste caso, os pontos de vista pertencem a uma voz que se imiscui no discurso e que determina os valores que devem ser assumidos.

A distinção entre as diversas vozes leva Ducrot a postular eventos polifônicos e a explicar, à sua maneira, a negação, a ironia e a pressuposição, por exemplo. Seja o exemplo: Mãe, você lava a louça pra mim? Haveria, no enunciado, um locutor que se responsabiliza pelo enunciado e outro que se marca como primeira pessoa: um é do discurso; o outro é do mundo. Mas há também, pelo menos, quatro enunciadores: um que afirma que a louça deve ser lavada (foco da higiene, sanidade e organização: mescla de medicina e administração); outro que afirma que, entre o adulto e o adolescente, cabe a este realizar a tarefa doméstica (ponto de vista da hierarquia familiar); outro, ainda, que determina que filhos não podem dar ordens aos pais (ponto de vista das relações pessoais); e, por fim, um que fixa que o trabalho vem antes do laz̧er (ponto de vista da primazia do trabalho sobre o lazer).

Em enunciados contrajuntivos, como Estudei muito, mas não passei no vestibular, poder-se-ia ouvir uma voz que $\operatorname{diz} \boldsymbol{A}$, estudei muito, e conclui $\boldsymbol{B}$, não passei no vestibular. Para que este encadeamento seja possível, é preciso ouvir uma terceira voz, $\boldsymbol{C}$, que afirma que quem estuda muito passa no vestibular, o que não acontece, pois, ad hoc, o princípio não se aplica. Talvez a justificativa ocorra em termos de outros terem estudado mais. De qualquer forma, em $\boldsymbol{C}$, estaria a voz do enunciador que sustenta a contrajunção. Este é um ponto crucial para as reflexões, pois é dessa voz sorrateira que sustenta as imbricações e transversalidades que se está à caça: mais do que perceber as partes explícitas de um enunciado adversativo, o interesse incide sobre a revelação da voz que baliza a discursividade. 
Constituídas essas figuras discursivas, Ducrot postula que os discursos resultam de um coro polifônico e que o enunciado é feito de uma tessitura permeável que é cosida por várias vozes que se sustentam e se chocam, mostrando "a necessidade que todo discurso tem de pôr em cena outro discurso" (p. 159). Assim, o sujeito que poderia parecer uno é constituído por uma profusão de vozes que sustenta o dizer.

O conceito de polifonia de Ducrot permite um insight sobre as contrajunções. Para que a relação possa ser realizada, o locutor afirma $\boldsymbol{A}$ e, valendo-se de $\boldsymbol{C}$ (o diz-se cultural, social, ideológico, moral, jurídico, religioso ou outro), orienta para $\boldsymbol{B}$, que, neste caso, contradiz uma conclusão "óbvia" a que o outro seria levado, não fosse a ressalva manifestada em $\boldsymbol{B}$. Pode-se afirmar que, nas relações contrajuntivas, o produtor do discurso é clivado por vozes e revela um ponto de vista enunciativo que não lhe pertence e que, à revelia, orienta o seu dizer e o faz defender valores. Trata-se, aqui, de determinar que valores são esses, quando o tema é a longevidade. Busca-se captar a distribuição positiva ou demeritória que se organiza sobre uma das ilhas cronológicas em que os homens são divididos.

\section{UM EXEMPLO GERAL}

Analisa-se um recorte d'O Crime do Padre Amaro, de Eça de Queirós, como exemplo, buscando apontar que a polifonia do excerto é ditada por crenças de ordem social e discursiva, o que vale para os enunciados contrajuntivos. Ferrão, abade confessor que possui uma forma de compreender a relação do homem com Deus, não elogia uma voz e rejeita outra por ditames de ordem individual, mas por uma forma social de atribuição de sentido.

Contra a debilidade dos homens, erguia-se um Deus tirano. Amélia e Amaro são a fragilidade humana e o horror que toma a alma do pecador: um quadro criado, para o abade Ferrão, pela igreja herdeira dos tribunais inquisitoriais. Eça de Queirós, o autor, põe Amélia em introspecção e, valendo-se do narrador onisciente, faz com que a moça reflita:

(1) Ah, fora decerto Nossa Senhora, compadecida enfim dos seus tormentos, que lhe mandara do Céu aquela inspiração de se 
ir entregar toda dorida aos cuidados do abade Ferrão! Parecia-lhe que deixara lá, no seu confessionário azul-ferrete, todas as amarguras, os terrores, a negra farrapagem de remorso que lhe abafava a alma. A cada uma das suas consolações tão persuasivas sentira desaparecer o negrume que lhe tapava o Céu; agora via tudo azul; e quando rezava, já Nossa Senhora não desviava o rosto indignado. É que era tão diferente aquela maneira de confessar do abade! Os seus modos não eram os do representante rígido dum Deus carrancudo; havia nele alguma coisa de feminino e de maternal que passava na alma como uma carícia; em lugar de lhe erguer diante dos olhos o sinistro cenário das chamas do Inferno, mostrava-lhe um vasto Céu misericordioso com as portas largamente abertas e os caminhos multiplicados que lá conduzem, tão fáceis e tão doces de trilhar que só a obstinação dos rebeldes se recusa a tentá-los (2000, p. 311-312).

Pela intromissão na consciência de Amélia, o autor a torna portavoz e a faz esboçar um quadro singelo da igreja, que poderia ser o alento para quem se achasse carente. Contra a Negra farrapagem em que Amélia se via, Ferrão fazia-lhe compreender que esse remorso que lhe abafava a alma resultava da atividade clerical e incutia no seu espírito outra relação com Deus. Negra é selecionado por um mirante social que revela a falibilidade humana, quando sob outra percepção. Contra a negra roupagem, Ferrão, dada a "sua" concepção de religião, fazia desaparecer o negrume que the tapava o Céu. Contra o Deus carrancudo, Ferrão sinalizava com um ser feminino e maternal. Contra o sinistro cenário das chamas do inferno, o abade falava de um Céu misericordioso; contra as portas fechadas para os pecadores, ele lhe mostrava portas largamente abertas; contra caminhos difíceis de trilhar na busca da salvação, mostrava a Amélia caminhos fáceis e doces.

Há, no excerto, uma intrincada rede de vozes, constituída por cinco miradas: Amélia, locutora do enunciado, é atravessada pelo discurso do abade Ferrão; a voz do confessor, que se posta contra Amaro e o clero; a voz do clero; a voz de Eça de Queirós (o autor), que se vale dos dois primeiros para poder ocupar outra mirada; a voz de um enunciador genérico (o diz-se social) que estaria tomando corpo contra a igreja católica e da qual o romancista se faz porta-voz. Pela relação que estabelece com o clero tradicional, rejeitando o terror e o medo criado, Ferrão se constitui a partir do discurso do outro, desta forma devendo 
ser lido no seu direito e no seu avesso: deve-se perceber por que Ferrão concebe certos fenômenos de forma negativa, colocando-os em outro diapasão.

$\mathrm{Na}$ voz de Amélia, as vozes do clero tradicional e do novo confessor se revelam e a moça valoriza negativamente um e positivamente o outro. Por meio de uma polifonia tecida a partir de cinco vozes, o autor valoriza uma concepção de mundo e desvaloriza outra. Elas são vozes que se constituem na sociedade do autor e a sua atividade discursiva lhes dá vida, para se postar ao lado de uma e rejeitar a outra, criando um palco em que duas doxas se digladiam e levam à escolha das vozes que compõem a trama textual. Vê-se que os discursos escolhidos não possuem uma verdade intrínseca; a relação supostamente natural que tecem com a vida vivida se faz sob a submissão à injunção de valores de uma concepção social.

\section{UM EXEMPLO PONTUAL}

Esta seção objetiva explicitar como se aplicaria a noção de polifonia à constituição dos enunciados contrajuntivos, assumindo que a sua organização é polifônica e que a articulação que se realiza entre as partes retoma uma voz discursiva que fornece o solo necessário para que o encadeamento seja admissível. A contrajunção permite perceber os ditames do discurso, levando a inferir que o interlocutor possui implícitos que o submetem ao ideário disseminado, embora uma ressalva pontual e esporádica aconteça.

Pode-se afirmar que uma contrajunção se apoia num silogismo entimemático, assume a premissa que o sustenta e põe sob suspeita o caso com que se depara porque provoca uma brecha nas grades que aprisionam sujeitos a filtros de julgamento: ele é sempre, neste sentido, contrassilogístico. A contrajunção é construída a partir de uma voz genérica, negando que ela se aplique a um caso específico, tendo, em decorrência, uma natureza polifônica, pois o seu escopo se pauta num princípio "axiomático" que remete às condições socio-históricas. Um enunciado contrajuntivo é, simultaneamente, contrassilogístico e polifônico: por negar que o silogismo consensual seja aplicável e por negar o seu ditame deveria se aplicar. Busca-se, na sequência, indicar que enunciados contrajuntivos se opõem ao silogismo de verdade de uma comunidade, sendo, por isso, polifônicos. Eis um dado: 
(2) Ele é um jogador que peca por ser afoito demais. Às vezes, a sua vontade de definir as coisas sozinho faz com que ele seja displicente. Mas as pessoas devem entender que ele ainda é jovem e tem muito tempo para se tornar um jogador maduro.

O enunciado é de Luciano do Valle, da Bandeirantes, ocorrido em dia 2 de agosto de 2009, às 16h40min, no jogo entre o Coritiba e o São Paulo. Keirisson, um jogador jovem, teria deixado de fazer um gol, em virtude do preciosismo da execução da jogada. Percebe-se que a contrajunção é criada pelo confronto entre as atitudes do atleta em campo e o que poderia ser a resposta do torcedor e dos comentaristas esportivos: a rejeição e a crítica. A afoiteza, o individualismo e a displicencia do atleta, que teriam levado a causar um prejuízo para o time, são assumidos como razão para ele sofrer retaliação ou reprimenda. Mas o narrador assume que o comportamento do jogador não deve sofrer represálias, pois há uma razão para ele ocorrer e dever ser desculpado: a juventude.

Pode-se explicitar o silogismo que ancora o narrador: a premissa maior assume que a afoiteza, o individualismo e a displicência devem ser punidos, a premissa menor observa que Keirisson está sendo afoito, individualista $e$ displicente; a conclusão deveria ser que $o$ atleta deve ser punido. Pode-se fazêlo de outro modo, em face do fechamento do enunciado: a premissa maior ditaria que a afoiteza, o individualismo e a displicência revelam imaturidade; a premissa menor indicaria que Keirisson estaria sendo afoito, individualista e displicente; a conclusão seria que $o$ atleta está sendo imaturo, o que levaria à rejeição e à culpabilidade do transgressor. Seja por um caminho ou por outro, a punição se justifica. Mas há uma razão para que o locutor não a aceite: as pessoas devem entender que ele ainda é jovem. Ou seja, as atitudes do atleta se deveriam à pouca idade, o que justificaria a inconsequência.

$\mathrm{Na}$ via do contrassilogismo, o enunciado contrajuntivo assume que a premissa maior é justa, devendo apenas ser re-avaliada no caso em foco: isto é, o silogismo é, paradoxalmente, assumido e negado; assumido, porque é entendido que se aplica à afoiteza, individualismo e displicência; rejeitado, porque é assumido que, no caso do atleta, que é jovem, ele deve sofrer uma suspensão. Na constituição polifônica, 
podem-se detectar, pelo menos, três vozes: uma que afirma que ser individualista, afoito, displicente e imaturo (poder-se-ia ouvir, em cada caso, uma voz manifestando qualificações negativas, porque é atravessada pelos discursos religioso, econômico e psicológico e por valores de origem idealista, e cristã, e romântica) é indesejável; outra que afirma que, como atitudes perniciosas, devem ser punidas (instaurando o erro, a culpa se estabelece e se forja a punição); e outra, por fim, a do narrador esportivo que, como locutor enunciador, antecipa-se ao julgamento e, agindo como advogado de defesa, argumenta a favor do réu desculpabilizando o equívoco.

O enunciado leva a um vislumbre da injunção valorativa sobre os tempos cronológicos dos homens. A afoiteza, o individualismo, a displicência e a imaturidade são indesejáveis e devem ser punidas. Mas há momentos em que são mais aceitáveis: a juventude seria um caso, o que não significa compreender que o seu aparecimento pese a favor do jovem. Ele vive uma ilha de transição em que algumas atitudes são, por um tempo, desculpáveis, mas não ignoradas. Diferentemente da infância, em que esses traços são compreendidos, embora não deixem de ser submetidos à correção, e da juventude, em que devem ser submetidos a uma coerção vigilante, no mundo adulto, se vierem a acontecer, a recriminação, a exigência e a determinação se fazem de uma forma inflexível e peremptória.

\section{VELHO, MAS (VELHO)}

Enfim, alcança-se o fio da meada pretendido. O discurso discretiza as faixas etárias em quatro blocos, com três sendo submetidos a enunciações e um ficando relegado ao silêncio, que é rompido quando rompe com o acordo social. Estão na origem de uma profusão de enunciados a velhice, a juventude e a infância (mais a velhice do que as outras duas), com a fase adulta ficando fora do alvo de pronunciamentos. Quando acontecem, eles ocorrem no sentido de repudiar e tripudiar atitudes que não seriam compatíveis com o que se espera de um adulto equilibrado. Quanto à velhice, ela é foco de observação privilegiado. Mais do que a infância, que se encontra ao abrigo da "inocência", do que a juventude, que pode contar com a complacência que justifica a pouca maturidade (imaturidade e 
inconsequência são tomadas, às vezes, como equivalentes positivos de jovialidade), e do que a fase adulta, que só se torna tema nos casos de transgressão e goza de aparente silêncio elogioso, a velhice é observada constantemente e, exceto quando sugere tradição e conhecimento, embora, nestes casos, seja aplicada mais a coisas do que a pessoas, ela é apontada como indesejável.

O enunciado a seguir foi proferido por um comentarista da ESPN Brasil, em 22 de março de 2009, no canal 48, às 23h6min, falando do que tinha acontecido entre os times do Atlético Paranaense e do Sport de Recife.

(3) - E o velho, mas sempre oportunista, Paulo Bayer, ampliou a contagem do Sport de Recife para 3 a zero ainda no final do primeiro tempo.

O comentarista estava às voltas com as impressões sobre os jogos do campeonato brasileiro e, dentre outras, a partida referida era contemplada. Durante o programa, tornou-se mote do discurso o fato de o atleta referido ter "arrebentado com o adversário", pois, além de contribuir para que os outros gols fossem marcados, ele tinha feito o terceiro, num lance de esperteza, habilidade e agilidade. Pode-se afirmar que a surpresa do locutor se deve ao fato de o jogador ser velho, o que o impediria de ser oportunista, traço positivo (diferente de aproveitador e explorador) equivalente a ágil, habilidoso, inteligente e atento.

A contraposição que surpreende se deve a Paulo Bayer, um velho, mostrar que se mantém oportunista e ampliar o placar. O questionamento se refere, pois, aos motivos de o narrador contrapor velhice e oportunismo, como se uma qualificação devesse ocorrer na ausência da outra, criando uma relação "logicocondicional" excludente entre velho e oportunista: se alguém é velho, não pode ser oportunista e, se alguém é oportunista, não pode ser velho. Essa articulação permite perceber uma voz que atribui traços negativos à velhice, pois agilidade, habilidade, sagacidade e atenção não se encontram dentro das expectativas em relação a ela. Embora o caso do atleta não corrobore a crença difundida e se encontrem inúmeros exemplos iguais, o narrador faz coro à voz que o ancora e lhe lembra a decrepitude "natural" que afeta a longevidade. Não 
é o exemplo empírico ou outras ocorrências que embalam o locutor: uma voz que atravessa os séculos alimenta o seu imaginário, levando-o a uma ressalva tênue frente ao princípio de validade geral: o princípio normativo do silogismo está salvo, mesmo que já tenha caducado. Em suma, velhos, frente ao culto ao corpo, do padrão de beleza jovem e da produção material, não são imagens apreciáveis e apetecíveis.

Considerando a parte do enunciado articulada por meio de contrajunção, percebe-se o encadeamento que é efetuado: a) a premissa maior dita que velhos não são oportunistas (hábeis, ágeis, atentos, inteligentes, espertos, talentosos ou outro efeito de sentido deste eixo de equivalência) ou que velhos são pouco eficientes (e, por decorrência, aplicamse quaisquer qualificativos desse diapasão de apreciação); b) a premissa menor indica que Paulo Bayer é velho e deveria, portanto, c) levar o comentarista e o espectador a concluírem que $o$ atleta é lento, desatento e inábil: portador dos traços com que o imaginário transfigurou o velho, tornando-o inútil, dada a fragilidade que, fisicamente, abate o seu corpo, sem perceber que debilidade não significa incompetência mental ou física para a vida prática. A transposição rasteira e apressada do mundo físico para o psicológico impõe sobre o velho um conjunto de mitos que, como mitos, nada justificam. Mas esses mitos fazem com que o dito acabe sendo, não porque é, mas porque se diz que é e se acaba crendo: diz-se que é e a injunção faz ser.

Pairando sobre o enunciado do comentarista, há uma voz que determina como ele deve acontecer, ditando-lhe crenças, juízos e avaliações e impondo que ele seja feito de um modo. Essa voz, que torna o enunciado polifônico, está na origem do silogismo: ela fornece o ancoradouro em que se sustenta o arrazoado e a ela se recorre no caso de justificar o que se afirma, se é que se deve fazê-lo. Velhice, debilidade, decrepitude, incompetência, desatenção: imbricações que são retomadas como verdades com que a providência divina teria cercado a sapiência da existência dos homens.

Para a sociedade pautada na produção material exacerbada; na vertigem da superação do que no dia anterior era uma inovação tecnológica; no culto do corpo contornado, torneado e sarado, mesmo que, para essa obtenção, façam-se sacrifícios e se invistam altas somas que são negadas para que uma vida possa ser mais digna; no hedonismo do prazer fugaz que se desfaz como brisa que apaga o agora para viver o 
depois; na tática para tirar proveito da vida e das vidas, sem ética que imponha freio às vontades sôfregas e trôpegas, parece não haver espaço para o velho a não ser os lugares que o escondem do mundo, não para o prazer, mas para a denegação daquele para quem ainda não chegou o tempo, permitindo-lhe crer que está ao abrigo das injunções físicas inexoráveis.

O enunciado abaixo foi pinçado de um jurado do programa American Idols, da Warner Bros, dito para uma participante do programa, em 16 de abril de 2009.

(4) - Você parece uma atriz hollywoodiana típica e parece saída de uma capa de revista dos anos dourados do cinema norteamericano. Mas vou ter que, muito polidamente, dar um não a você. Você não aguentaria ir até o final.

O comentário apresenta razões fortes para avalizar a permanência da candidata, pois ela parece uma atriz hollywoodiana típica e parece saída de uma capa de revista dos anos dourados do cinema norte-americano, constatações que deveriam colocar o analista a seu favor, pois, conforme indica o enunciado, o fato de a mulher apresentar os traços destacados deveria ser lido pelo filtro positivo. A candidata apresentava características para os jurados se posicionarem a seu favor: fez uma bela apresentação e teve uma presença em cena que remetia ao tempo da infância, das mitologias e das idealizações do locutor, reveladas por meio do uso de atriz. hollywoodiana, capa de revista e anos dourados: argumentos meritórios. Pela permissão do retorno à infância re-visitada e idealizada, a conclusão lógica seria que ela não deveria sair do programa. Por ter os traços que tinha e por estar num programa que requer que eles existam, o procedimento do analista deveria ser a aprovação da candidata. A lógica se ancora na crença de que parecer atriz hollywoodiana e parecer saída de capa de revista são características positivas e, se a candidata as tem, deveria ser bem avaliada: mas o resultado é outro, o que, a rigor, sugeriria incoerência do jurado.

Apesar da conclusão lógica imposta pelos atributos da mulher, o resultado a contradiz e o jurado afirma ter que, muito polidamente, dar um não à candidata. Se, como ele acaba de reconhecer, deveria manter a 
senhora no programa, por que age contrariamente ao previsto? O que o motiva a dar um não? E por que deve fazê-lo polidamente? Por que acha imprudente manter a senhora no programa para as etapas seguintes? Se ele explicita um conjunto de traços favoráveis a ela, se argumenta a seu favor, o desfecho para a apreciação seria a de ela permanecer na competição. O não sugere despropósito. Mas há uma razão para que o jurado tome uma decisão que parece contradizer a expectativa e que justifica o fato de a negativa ser feita polidamente, ao contrário de recusas derrisórias e humilhantes: ela se vale da profecia de que ela não aguentaria ir até o final: como, se o desempenho foi satisfatório?

Há que se atentar para o que leva o locutor a afirmar que o não deve ser dado muito polidamente. Essa atitude não deriva de uma imposição sobre a forma de os jurados tratarem os competidores, pois há vários casos de candidatos tratados com deboche, havendo os que se irritam e agridem verbalmente os jurados na presença da plateia; e não deriva de um ditame pessoal que faça esse jurado dispensar um tratamento distinto aos candidatos, pois ele é um dos que mais acintosamente os faz entender que não deveriam se apresentar. E polidamente não se deve a respeito ou deferência aos idosos, por serem dignos de valoração diferenciada em virtude da distinção que teriam logrado alcançar. $\mathrm{O}$ termo, enfatizado por muito, tem uma razão de ser: a candidata ter a idade que tem e, por isso, ser vista com frágil, devendo ser tratada com ternura e docilidade para não ser ameaçada em sua fragilidade. $O$ tratamento não é ditado por um valor positivo intrínseco ao velho que o faria ser tratado com deferência; o não a ela ocorre dessa forma pela percepção do idoso como débil e de pouco vigor. Como se vê, à menor capacidade física, associa-se menor tenacidade e força de enfrentamento. Mais do que distinguir o velho, polidamente busca construir a imagem de bom moço, que desempenha este papel em face da concepção do idoso como um ser que sucumbe a qualquer açoite.

Ter que, muito polidamente, dar um não, por outro lado, coerentemente do ponto de vista discursivo, imbrica-se com a profecia de que a candidata não aguentaria ir até o final. $\mathrm{O}$ desempenho da participante foi satisfatório e ela possuía os atributos indicados pelo jurado. Deve-se considerar que o programa, de auditório e com uma participação semanal de poucos minutos, não exigia uma atividade hercúlea que um idoso não pudesse suportar. Mas, à revelia das evidências, uma cegueira se impõe e 
impede que o locutor admita a competência da candidata e perceba a inadmissibilidade da sua previsão. A imagem de sujeito bondoso, paternal, precavido, cuidadoso e atencioso do jurado é ditada, pois, a partir de um princípio cultural que aposta na fragilidade do velho e na atenção que se deve ter com a figura materna, pois a candidata relembra ao jurado o seu papel de filho cuidadoso e lhe impõe um leque de atitudes para ser sancionado positivamente. Nenhuma razão mais objetiva determina que a candidata seja eliminada do programa a não ser por ser idosa, o que impõe que seja protegida e impedida de realizar esforços para os quais, supostamente, não tem vitalidade. Eis uma "evidência" difícil de desfazer, dada a inculcação simbólica e a interpelação a que todos são submetidos no processo de aquisição dos saberes "necessários".

Pode-se explicitar o "silogismo" em que o locutor se ampara, aproximadamente, por parecer uma atriz, hollywoodiana e parecer saída de uma capa de revista dos anos dourados do cinema norte-americano depõe favoravelmente ao candidato do programa American Idols. A candidata tem as duas características; o jurado, portanto, deveria ser favorável à sua permanência no programa. Porém, contrariamente a este ditame, há outro, ainda mais forte, que o faz recorrer à contrajunção para negar a aplicação: a participante não aguentaria ir até o final; ele deve, portanto, muito polidamente, dizer-lhe não e evitar que seja submetida a um esforço para o qual não tem preparo. Há, pelo menos, duas vozes que polifonizam a visada do locutor: a primeira, que se pronuncia sobre uma imagética e uma proveniência, colocando-as como meritórias; a segunda, que diz o que é a velhice e como se deve agir em relação a ela, principalmente se for relativa a candidatas, pois conjugam os papéis de mãe e de mulheres.

O turno transcrito a seguir é emblemático, porque funciona como uma síntese do juízo de valor que se possui sobre os idosos: ser velho é ofensivo e pode causar dor e mágoa. Ele ocorreu no seriado Fringe, da Warner Bros, em 17 de maio de 2009, às 23h20min, e foi proferido por Peter Bishop.

(5) - Quando voltei a ver meu pai, ele achou que eu estava mais gordo. Mas, velho, isto magoa um pouco. 
No seriado, Peter é filho de Walter Bishop, cientista brilhante, que tem momentos de infantilidade, ingenuidade e senilidade. Investigando casos incomuns, a equipe tem em Walter o elemento de explicação para os fatos que parecem não ter uma causa racional. Os episódios estudados pelo grupo vão de pré-cognição, teletransporte, percepção sensorial, até passagens para mundos paralelos. Em geral, Walter está ligado aos fatos que ocorrem, em virtude de serem relacionados às suas experiências científicas que vão parar em mãos inescrupulosas.

Em Fringe, há três pessoas que compõem a equipe de trabalho de Walter e um deles é Peter, que, dados os episódios de insanidade mental do pai, resiste a uma relação cordial com ele e se recusa a ser cientista, imaginando que ceder à "vocação" o fará ser "anormal" como Walter. Peter, em razão de descaminhos, casou-se, mas se separou e o enunciado acima ocorre quando ele reencontra a ex-esposa e conta como se deu o re-encontro com o pai.

O enunciado revela que, conforme a percepção do pai, Peter teria mudado em dois aspectos: estaria mais gordo e mais velho, sendo que estas características forjam efeitos de sentido negativos, com a primeira estando numa escala de valoração demeritória inferior à segunda. Para Peter, ao rever o pai, este o teria achado mais gordo e mais velho, sendo estas percepções pertencentes a um eixo de valoração que depõe contra o portador; mas, se ser gordo é ruim, ser velho é pior, tanto que chega a magoar.

O enunciado de Peter poderia ser parafraseado por algo como: ao voltar a ver men pai, de acordo com a percepção dele, en estava mais gordo e, para a voz. social corrente, isto não é uma característica valorada de forma positiva, dada a percepscão estética e sanitária que se tem do corpo obeso; no meu caso, inclusive, en estaria mais gordo, o que me leva a pressupor que, antes, en já era dado como possuidor dessa característica e, portanto, haveria um olhar negativo do meu pai (e da sociedade) sobre mim, o que me dispõe contra ele (eis uma das razões para as desavenças de Peter e Walter, pois o segundo é crítico em relação ao primeiro); mas ser gordo, de qualquer modo, não deve ser visto necessariamente como ofensivo, pois, em geral, a atitude frente à obesidade é mais de alerta e de motivo para algum preconceito, do que propriamente de discriminação mais contundente; não devo sentir-me magoado com isso; mas meu pai também achou que eu estaria mais velho e, 
já que, entre ser velho e ser gordo, há um descompasso desfavorável para a velhice, isso fez. com que eu me sentisse magoado. Como se percebe, há um ditame social que leva Peter a ler o enunciado de Walter como demeritório, pois ele sugere desleixo e pouco cuidado e constata um traço sobre o qual pouca coisa se pode fazer. Se a gordura pode ser combatida, a velhice é inexorável. Para todos os efeitos, a velhice é ofensiva e provoca mágoas.

A reflexão de Peter, em termos silogísticos, ocorre da seguinte forma: a) a obesidade é uma característica negativa; b) men pai me considera obeso; c) estou, portanto, sendo visto negativamente por ele. Como a obesidade é algo controlável, ele deve me julgar alguém desleixado e de pouca força de vontade. Mas ser julgado mais gordo não é uma percepção que deva ser levada tão a sério, pois o locutor a contrapõe a outra, fazendo dela o tema central de reflexão. Ser gordo é aceitável, mas ser velho magoa um pouco. O encadeamento se faz por: a) a velhice é uma característica negativa; b) meu pai me vê como velho; c) ele, portanto, está me vendo negativamente. Mas, neste caso, dada a diferença de percepção entre ser gordo e ser velho, a constatação de Walter magoa um pouco. E magoa tanto por ser a revelação de como o pai avalia o filho, quanto por ser a percepção social que se abate sobre Peter e Walter, fazendo deste o juiz da aparência daquele.

Misto de reflexão entimemática que se sustenta numa disposição cultural que distingue corpos e faixas etárias e de constituição polifônica que fornece as evidências para discretizar o mundo e sancionar os seus membros, o enunciado de Peter é emblemático, porque ele não toma a velhice como negativa em relação às características que a constituem, mas se refere a ela de forma genérica. Não é a debilidade ou a fragilidade ou outro traço da velhice que é tomado para o juízo demeritório que realiza, mas é a velhice que é dada como fonte de mágoa, quando alguém constata que é aplicável a um corpo qualquer. Elemento condensador de um juízo avaliativo feito sem um procedimento analítico acurado, velho é demeritório e magoa quem é dado como portador, sugerindo um modo de ofensa e de agressão.

Quando os enunciados remetem a pessoas, não há condescendência em relação à passagem do tempo: o desgaste que se abate sobre os corpos longevos leva à imposição de efeitos de inutilidade e de obsolescência sobre as marcas sulcadas pela exposição à fatalidade da vida, tornando-se uma ofensa. Porém, é de outra ótica valorativa que a resistência ao tempo é avaliada, quando as enunciações se pronunciam 
sobre um objeto. Dado o fato de que a sua constituição física lhe dá maior durabilidade e permite transcender gerações permanecendo intacto, o desejo de comungar a perenidade e a eternidade que o constitui, um poder sonhado por todo homem, leva a pô-lo a salvo da derrisão do mundo e do desgaste do tempo. Os museus parecem ser os sarcófagos em que o desejo de manutenção da vida por um período maior se agrega aos objetos dignos de preservação, seja essa dignidade devida à durabilidade ou à importância: duas ambições da existência humana. Não se erigem pirâmides nem se procede à mumificação por alguma espécie de diletantismo artístico ou científico. A velhice e o desgaste temporal são julgados de forma desigual, quando percebidos em objetos ou homens: no primeiro caso, a durabilidade é resguardada e constitui o espelho em que cada um deseja ver a sua imagem; no segundo, a atitude de relegar à invisibilidade e ao esquecimento (os asilos são os emblemas da denegação do desgaste físico que é inevitável) enseja a contraidentificação com a fugacidade da vida e a transitoriedade.

Quanto a como a velhice dos homens é visualizada, os exemplos anteriores bastam. Quanto à sua compreensão quando se liga a objetos, considerem-se os enunciados analisados à frente. $\mathrm{O}$ primeiro foi retirado da Nova Gramática do Português Contemporâneo, de Cunha e Cintra (1985). O segundo foi colhido do programa Terra Padroeira, do Canal da Aparecida, no sábado, às 22h, em 22 de agosto de 2009. Ele foi proferido por Cléber.

(6) A igreja também era velha, porém não tinha o mesmo prestígio.

(7) - É muito antigo, mas muita gente trabalhou com um instrumento desses. Portanto isto deve ser guardado como uma relíquia: faz parte das lembranças de muita gente de bem.

Em 6, os autores retiram o exemplo de uma obra literária, sem que explicitem qual é ela. Para todos os efeitos, importa perceber como o autor do enunciado relaciona velha e prestígio. O marcador de pressuposição também permite inferir que a igreja é um dos objetos postos à parte em relação a outros, sejam eles outras igrejas ou coisas quaisquer. Mas, ela não partilha do prestígio que os caracteriza por serem velhos. 
Sendo esta a característica que lhes confere um traço meritório, contra as evidências, ele não é aplicável a ela por ser velha: embora devesse, ela não tem o prestígio dos demais.

A reflexão do locutor parte da premissa de que coisas velhas têm prestígio, de que a igreja era velha e da conclusão aplicável ao caso de que $a$ igreja, portanto, teria prestígio. Esta, porém, não é uma conclusão que deva ser feita, precisando, portanto, ser negada para evitar uma leitura indevida. Para a construção da relação contrajuntiva, o locutor se vale do conectivo mas, antecipando-se à aplicação do silogismo ao caso e negando a aplicabilidade à igreja em evidência. Pode-se afirmar que um "diz-se" anterior atravessa o intradiscurso, fazendo-o afirmar que coisas antigas têm prestígio, mas isso não se verifica no caso do objeto destacado: $\mathrm{e}$ apenas nele, não sendo válido para outros casos. O princípio de crença, como se vê, permanece intacto, ocorrendo uma ressalva apenas sobre um observável particular.

Note-se que o prestígio constituinte da velhice não se refere a pessoas, mas a objetos. A substituição de igreja por homem, por exemplo, causaria uma estranheza explicável a partir de duas razões pelo menos: a primeira, porque não se produzem enunciados com este tipo de encadeamento em relação a pessoas; e a segunda, porque não existe no solo de crenças uma premissa de que pessoas velhas (por serem velhas) possuem prestígio. Esta articulação pecaria por ilegitimidade discursiva: pior para o homem. Pode-se afirmar que o sustentáculo que ancora o locutor determina que a longevidade do homem seja tão mais negativa, quanto mais for duradoura, e que a longevidade dos objetos seja tão mais positiva, quanto mais perdurarem no tempo: obsolescência da humanidade, sacralização da realidade. Não deve ser gratuito que um diamante custe o que vale uma vida inteira de trabalho da grande maioria dos homens.

Em 7, o apresentador cria uma relação contrajuntiva entre a antiguidade do arado e o fato de muita gente ter trabalhado com ele, o que permite inferir a avaliação positiva do referente do discurso, pois ele foi útil para quem recorreu aos seus préstimos. Conhecidas as condições em que se realizava o trabalho agrícola, sabe-se da relevância que o arado teve para o homem do campo. É ela que permite que o autor faça o encadeamento conclusivo que se verifica e apresente o argumento final a 
favor da sua tese, à guisa de lambuja, fechando, com isso, a defesa de seu ponto de vista.

Percebe-se que a contrajunção é feita entre a primeira parte do primeiro enunciado e o enunciado introduzido por portanto, estando neste a relação de contradição que se faz entre as duas partes do primeiro e sendo dever ser guardado como uma relíquia a oposição a uma atitude vislumbrada que é motivada pelo fato de o objeto ser antigo. A parte do enunciado encabeçada pelo mas funciona como uma causa para o cuidado de guarda do arado e se soma ao argumento que é apresentado como razão para a assunção da tese do autor. Sobreposições ou superposições à parte e recolocações ou aceitação do enunciado como aparece, importa perceber que o motivo para as relações enunciativas se articula ao redor da constatação da velhice do objeto e da ameaça da sua eliminação.

Entende-se que a reflexão parte da tese de que coisas antigas devem ser eliminadas, de que $o$ arado é antigo e da conclusão aplicável ao caso de que ele, portanto, será eliminado. Mas não é esta a atitude que o locutor entende que o seu espectador deva ter, negando-a por meio da apresentação de duas razões. Para estabelecer a relação contrajuntiva, o locutor usa o conectivo mas, antecipando-se à aplicação do silogismo. Um enunciado transverso se imiscui à tessitura do intradiscurso, fazendo validar que coisas antigas devem ser descartadas, mas que isso não se verifica no caso do arado. A voz interdiscursiva que antecede o discurso permanece rija, fazendo-se apenas uma ressalva sobre um dado particular. É sintomático o uso do termo relíquia, que aponta para a sacralização e reificação do mundo objetivo.

Embora não seja firme na distinção da forma de proceder em relação aos objetos e aos homens, já que valida a obsolescência e eliminação dos primeiros como premissa geral, percebe-se que o cuidado sagrado é aplicável a coisas antigas e não a pessoas. A aplicação de relíquia a velho, por exemplo, embora fosse possível, causaria uma estranheza explicável por não haver um valor cultural que afirme que pessoas velhas são relíquias, embora sejam. Se isso acontecesse, haveria uma ilegitimidade discursiva: e, de novo, pior para o homem. O solo de crenças determina que a velhice do homem é negativa e que a antiguidade dos objetos é positiva: obsolescência da humanidade, sacralização da realidade, mesmo que a pílula apareça dourada por 
argumentos causais que buscam estabelecer uma racionalidade para o postulado.

\section{ALGUMAS CONSIDERAÇÕES}

Confluência de acontecimentos inevitáveis, a velhice é discursivizada de modos que revelam o princípio comum de entendê-la: demeritória e pejorativa. Reconhece-se a pretensão das afirmações a seguir em face das análises. O leitor julgará a procedência dos pleitos ou os contradirá, quando insustentáveis. Não se tem um objetivo maior, ao trazê-los à tona, do que torná-los motivo para reflexões. Considera-se que, se os dados não permitirem a amplitude das generalizações, mesmo assim, alguma injunção causal existe para a mirada depreciativa sobre a velhice. Deve-se refletir sobre ela, indicando portas de entrada promissoras que possam ser pistas para estudos futuros.

Uma forma de explicar a percepção negativa do velho se situa na estética corporal atual. Em vez do corpo "sarado", com músculos definidos, o velho se caracteriza pela diminuição de massa muscular, sendo o oposto do que se julga o corpo desejável (ambiguamente); em vez de um corpo com pele lisa e viçosa, o velho porta um corpo desgastado pelo tempo, possuindo características combatidas por esteticistas, pelos meios de comunicação e pelas conversas que ocorrem nos locais de "beleza" corporal; e não se tem complacência com o fato de o tempo trazer a erosão que provoca sulcos que não foram escolhidos e se impuseram. Tudo se passa como se fosse possível parar o tempo e evitar os estragos: dever-se-ia atentar para as fortunas gastas e para os sacrifícios realizados na tentativa de frear a gravidade e a oxidação da pele, dos olhos e do coração. Que tais efeitos sejam ocasionados pela fatalidade não é razão para que o corpo velho passe incólume aos olhos dispostos a alijar aquilo em que se tornarão um dia: pode-se afirmar que a crítica, a ofensa e a injúria não são mais do que a singela pretensão de se achar infenso aos efeitos que alcançarão a todos. À luz de uma "estética" contornada por percepções masoquistas e pretensiosas, preconceitos, discriminações, traumas e repressões se efetuam, esquecendo-se que a roupagem do corpo não é um valor absoluto, que deve ser almejado pelo homem, nem o parâmetro que permite discernir o agradável e o desagradável, a não ser para uma lógica canhestra, 
reducionista e segregadora: ou excessivamente temerosa, pois não se combate aquilo de que não se tem medo.

Outro modo de explicar a segregação se encontra na ordem biológica. É normal que, com os anos, o corpo se torne mais frágil e débil, menos ágil e hábil, dados os abalos a que a vida social o submete e as injunções orgânicas e temporais a que é exposto, escolhendo ou não ser alcançado. Que os movimentos se tornem menos vistosos, que a força se torne menos vigorosa, que o poder de confronto se torne menos denso e que as contendas com o mundo façam atividades singelas parecerem hercúleas por referência a uma compleição física que se deteriora não desculpa quem não se comporta como um garoto. Se o tempo passou e o tornou fraco e lento, adoecido às vezes, não é desculpa para fraquezas e se cobra a autossuficiência que abandonará a cada um. Para uma sociedade apegada ao individualismo e ao hedonismo erótico, o velho não atende ao bom, ao belo e ao digno e traz tatuadas as marcas do desgaste que se tornam estigmas usados como meio de provocar uma cisão entre os que pertencem e os que não são bons sujeitos: e menos cabelos, rugas, movimentos lentos e olhos embaçados se transformam em signos de entrada ou não na praça dos que acedem a regiões prosaicas, como um clube de futebol, ou relevantes, como a família. Às vezes, a debilidade provocada pela passagem do tempo faz o velho ser visto como incompetente moral para a vida, vedando-lhe tarefas e atividades, em virtude de a fragilidade física ser transformada em debilidade prática e social. Também aqui a rejeição é a denegação do indesejável e a criação de membranas que buscam evitar que os olhos se deparem com as bolas de cristal que preveem o futuro: medo da morte, desejo de juventude e ambição de eternidade. Talvez não seja fortuito que igrejas e religiões sobrevivam e se fortaleçam, dado que os dois afetos iniciais são impossíveis e o último pode ser mantido como uma promessa pautada numa racionalização tênue.

Outra razão que justifica a carga negativa aplicada à velhice se encontra na fisiologia. A longevidade costuma afligir o homem com disfunções que afetam o funcionamento corporal e psicológico. No primeiro caso, há expectativas sobre respostas que o corpo deve dar para que funcione da forma esperada, realizando atividades que vão de necessidades fisiológicas primárias, respostas imprescindíveis para evitar situações constrangedoras, até funções que permitem que o corpo 
conceda qualidade de vida ao portador. Se as segundas garantem bemestar na vida cotidiana e dão acesso a prazeres que tornam feliz, os primeiros aproximam os atingidos a incompetentes submetidos a situações embaraçosas, fazendo-os perder a autoestima e se tornarem reclusos. No segundo caso, talvez a falta de lucidez e de memória seja o tema sobre que mais incidem obrigações e avaliações negativas, quando essas funções falham. Não é incomum haver idosos cujo corpo deixou de dar respostas satisfatórias em relação à fisiologia corporal física ou psicológica. Essas disfunções se tornam um peso para familiares, onerando-os com demandas indesejáveis e a que nem sempre estão dispostos a atender: incômodo, perda de tempo, irritação e impaciência são respostas aos que, atacados pelos anos, tornam-se dependentes numa sociedade pautada no individualismo. Um idoso é um obstáculo a ser removido para o mundo não sofrer sobressaltos. Porque é impensável que se tenha que perder tempo com um adulto incapaz, porque é inaceitável que quem era, muitas vezes, o leme de orientação dos demais agora depende de quem dependia dele e porque quem centralizava a organização passa a não encontrar um lugar no mundo e a repetir as mesmas coisas, o velho é recusado por significar a renúncia a momentos da vida em proveito daquele que renunciou a muitos da sua pelos seus. Eis um entrave à vertigem que afeta a vida e que faz com que a exigência de renúncia da ida ao shopping ou à casa do amigo para ver o jogo de futebol seja vista como afronta. Novamente, percebe-se a denegação do indesejado irrecusável para si, mesclado por pitadas de egocentrismo e de egoísmo.

Um quarto modo, por fim, de explicar a rejeição e a discriminação que se abate sobre o velho se refere a questões de ordem econômica. Contrariamente ao corpo jovem saudável e ágil que atende às demandas do mundo capitalista determinado pela produtividade de objetos de consumo, o idoso, devido aos lapsos de lucidez e memória, às falhas fisiológicas, às deficiências de rendimento corporal e à aparência que contradiz os ditames de um padrão de beleza ditatorial e despótico, deixa de possuir o perfil necessário para partilhar o mundo com aqueles que, em tese, estão em condições de atender aos ditames das linhas de montagem matematizadas e inexoráveis. Para o mundo pautado na força de trabalho como motor essencial, que deve atender a padrões parametrizados, um corpo mais lento, débil e frágil e menos saudável e 
belo não é pertinente, pois contraria a lógica dos recordes e do aumento indefinível da capacidade produtiva. Neste caso, não é necessário delongar-se na reflexão; não faltam estudos que apontam a incongruência produzida pela lógica do mundo do trabalho sob a ótica do capitalismo e o corpo necessário para atendê-la. A vertigem que comanda a cadeia produtiva (lapso irônico e elucidativo da nominalização) que, para se manter azeitada, deve produzir incansavelmente e tornar obsoleto o que produziu para que a imposição do consumo permaneça à disposição das entranhas famélicas da máquina destinada a produzir insatisfação perene traz como consequência a obsolescência também do homem, colocando-o, por meio da lógica que o determina, no mesmo fio de coerência que se aplica ao universo das coisas: descartabilidade, substituição, esquecimento e abandono. Para ambos, homens e objetos, com a diluição de um no outro por meio da personificação das coisas e da objetificação do homem, o destino é o mesmo para a lógica da produção de bens de consumo, cujo evento raro é o de objetos, e apenas eles, tornarem-se um clássico encerrado em museu, cuja antonímia cultural é os cemitérios destinados a apagar as lembranças, as histórias e os homens.

\section{REFERÊNCIAS}

BAKHTIN, M. Marxismo e filosofia da linguagem. Tradução de Michel Lahud e Yara Frateschi Vieira. 8. ed. São Paulo: Hucitec, 1997.

CUNHA, C.; CINTRA, L. Nova gramática do português contemporâneo. 2. ed. Rio de Janeiro: Nova Fronteira, 1999.

DUCROT, O. O dizer e o dito. Tradução de Eduardo Guimarães. Campinas: Pontes, 1987.

EÇA DE QUEIRÓS. O crime do padre Amaro. São Paulo: Ática, 2000.

Recebido em 20/12/09. Aprovado em 25/01/11.

Title: Contraposition and old age: tradition and obsolescence

Author: João Carlos Cattelan

Abstract: The present study focuses on the ordinary discourse (a kind of discourse based on trivia, on the ephemeral and on the repetition of the discursive order). The focus is on enunciations built with 
contrapositive connectives, particularly the adversative but. The attempt is to recapture the previous knowledge, which was produced earlier, in another place and independently, which crosses in a perpendicular way the discourse produced at the deictic axis of here and now, to access the pillars that command the articulations between each part of the enunciation. Thus one observes how contrapositive enunciations oppose propositions against each other, when the subject matter is related to longevity of man and things.

Keywords: Ordinary discourse. Polyphony. Contraposition. Old age.

Titulo: Contrajunción y vejez: tradición y obsolescencia

Autor: João Carlos Cattelan

Resumen: Este estudio se dedica a la observación del discurso común (un tipo discursivo que se pauta en la trivialidad, en lo efimero y en la reiteración del orden discursivo). El foco de análisis incide sobre enunciados construidos con conectivos contrajuntivos, en especial, con el mas adversativo, buscando rescatar el saber anterior, producido antes, en otro lugar e independientemente, que atraviesa perpendicularmente el discurso producido en el eje deictico del aqui y abora, y tener acceso a sustentáculos que comandan las articulaciones entre las partes del enunciado. Se buscará observar, así, como enunciados contrajuntivos oponen proposiciones entre sí, cuando la temática en pauta se refiere a la longevidad de los hombres y de las cosas.

Palabras-clave: Discurso común. Polifonía. Contrajunción. Vejez:

CATTELAN - Contrajunção e velhice... 